\title{
Looking for alien life
}

\section{Santa Cruz}

SOVIET scientists have offered to help their US counterparts in the largest-ever Search for Extraterrestrial Intelligence (SETI), scheduled to begin on Columbus Day 1992 in honour of the 500th anniversary of Columbus's discovery of America. At an international SETI conference in Santa Cruz early in August, the dozen Soviet participants offered US scientists access to the Soviet Union's three largest radio telescopes.

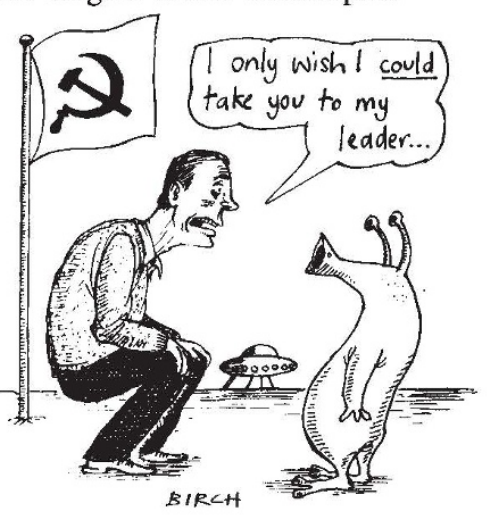

The National Aeronautics and Space Administration (NASA) is very interested in the offer, said Jill Tarter, the radio-astronomer who heads NASA's SETI effort, but a formal agreement may take several years to negotiate. If an agreement is reached, it will be the first collaboration between US and Soviet scientists in this specialized, speculative field.

Although NASA has been designing and building SETI equipment since the early 1970 s, the survey that begins next year will be its first major search, and in PUBLIC HEALTH

\section{New AIDS definition}

\section{Washington}

THE US government's new definition of AIDS, announced in this week's American Medical News, could double the official number of people with AIDS in the United States.

The new definition, expected to be implemented by the end of the year, will count anyone infected with human immunodeficiency virus (HIV) and having a CD4 lymphocyte count under 200 as having AIDS. The old definition - filling a multi-page document - defines a person with AIDS as one who is infected with HIV and has one or more of several dozen designated AIDS-related conditions such as Kaposi's sarcoma. A person with a CD4 count below 200 is likely to be severely ill, but may not have any one of the designated conditions.

"The new definition will allow the CDC [the US Centers for Disease Con- its first day of operation it is expected to dwarf all the smaller searches attempted over the past 32 years. The $\$ 100$-million, ten-year programme will include both a targeted search that examines 1,000 Sunlike stars within 100 light years of Earth and a sweeping sky search - a broader, less sensitive survey of the entire sky.

The targeted search will use several large telescopes - a 300-metre instrument in Arecibo, Puerto Rico, plus telescopes in West Virginia in the United States; New South Wales, Australia; and Nancy, France. It is this part of the programme in which Soviet collaboration could be helpful, as spacecraft-tracking telescopes in Evpatoria in the Crimea, at Ussuriysk near Vladivostok, and one under construction near Samarkand in East Asia would give NASA a much larger area for collecting signals.

In return, the Soviets would like to work with some of the state-of-the-art processors described by US scientists at the Santa Cruz meeting. The difficulty of SETI lies not so much in collecting signals as in determining their sources, and NASA has pushed for the development of new devices to distinguish between alien signals and run-of-the-mill interference from Earth. A processor designed by the Jet Propulsion Laboratory, for instance, will be able to scan half a billion channels for signals in the 1,000- to 10,000 -megahertz range.

What happens if they detect an alien signal? "We'll leave it to the political science experts to decide when to respond and how," Tarter says.

Stephanle Sansom

trol] to count cases more accurately, and to find out into which populations the disease is spreading," says Charles Fallis, a spokesman for CDC.

At present, almost 70,000 people in the United States have AIDS according to the old definition. About 120,000 have already died from the disease. The CDC estimate that a further 150,000 people will fit the new definition of AIDS.

The old AIDS definition has come under increasing fire from AIDS advocacy groups and epidemiologists who claim that it fails to reflect the true magnitude of the pandemic. Many of the defining diseases were picked because they affected HIV-infected homosexual men. But as increasing numbers of women, intravenous drug users and children become infected, physicians are discovering new AIDS-related diseases.

\section{'Hacker' to go on trial}

\section{Canberra}

FEDERAL prosecutors in Australia will call witnesses from the United States for the trial of a computer student accused of 'hacking' into sensitive computer systems at the US National Aeronautics and Space Administration (NASA) and the Lawrence Livermore National Laboratory in California.

Using a computer and a modem at his home in Melbourne, Nahshon EvenChaim, a 20-year-old computer science student, allegedly altered research data at Livermore and disrupted operations at a NASA computer facility in Hampton, Virginia, isolating the computer for 24 hours. Also penetrated were computers at the University of California, the University of Wisconsin, Purdue University in Indiana, the private Texas company Execucom Systems Corporation and the Australian science agency CSIRO.

Last week, Even-Chaim was committed to stand trial on $\mathbf{4 8}$ criminal charges. The trial will be a test case for computer hacking laws introduced in Australia in 1989.

During his committal hearing, it was alleged that Even-Chaim gained access to computers through the worldwide computer network Internet by exploiting loopholes in the Unix operating system. The court heard that Even-Chaim considered the breach of computer security at the Livermore laboratory to be his chief accomplishment. Brett Wright BIOTECHNOLOGY

\section{Australian company near to a blue rose Sydney}

THE Australian biotechnology company Calgene Pacific estimates that it will be marketing blue roses by 1997 , now that it has successfully isolated a blue pigmentation gene from other flowers. Such a rose cannot be produced by normal breeding techniques since roses do not have the necessary pigment.

The company says the blue roses will be sold initially at about US\$80 a stem.

Michael Dalling, managing director of Calgene Pacific, says the company has already developed an implantation technique for putting new genes in flowers by adapting a mechanism used by the crowngall disease virus. It has used the technique to alter the genetic makeup of other flowers, he says. For instance, Calgene recently grew a batch of several thousand carnations with a gene for extended life. The company still has to marry the gene implantation technology with the new gene, which was isolated from delphinium flowers, but believes it will be able to do so within schedule, Dalling says.

Mark Lawson 